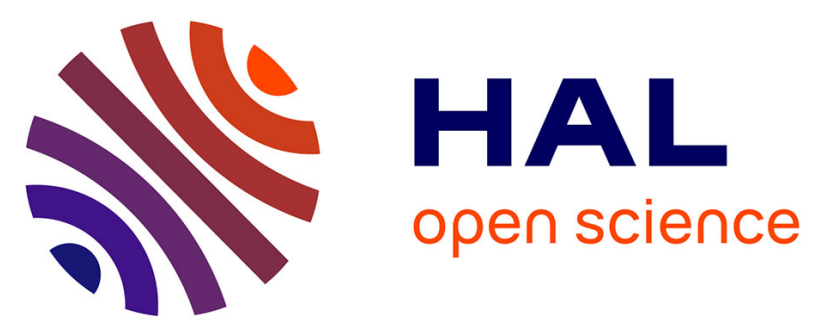

\title{
Antioxidant activity-guided isolation of constituents from Euphorbia gaditana Coss. and their antioxidant and tyrosinase inhibitory activities
}

Mohamed Ibrahim Badaoui, Abdulmagid Alabdul Magid, Laurence Voutquenne-Nazabadioko, Mohammed Benkhaled, Dominique Harakat, Anthony Robert, Hamada Haba

\section{To cite this version:}

Mohamed Ibrahim Badaoui, Abdulmagid Alabdul Magid, Laurence Voutquenne-Nazabadioko, Mohammed Benkhaled, Dominique Harakat, et al.. Antioxidant activity-guided isolation of constituents from Euphorbia gaditana Coss. and their antioxidant and tyrosinase inhibitory activities. Phytochemistry Letters, 2020, 39, pp.99-104. 10.1016/j.phytol.2020.07.012 . hal-03339949

\section{HAL Id: hal-03339949 \\ https://hal.univ-reims.fr/hal-03339949}

Submitted on 22 Sep 2021

HAL is a multi-disciplinary open access archive for the deposit and dissemination of scientific research documents, whether they are published or not. The documents may come from teaching and research institutions in France or abroad, or from public or private research centers.
L'archive ouverte pluridisciplinaire HAL, est destinée au dépôt et à la diffusion de documents scientifiques de niveau recherche, publiés ou non, émanant des établissements d'enseignement et de recherche français ou étrangers, des laboratoires publics ou privés. 


\section{Graphical Abstract}

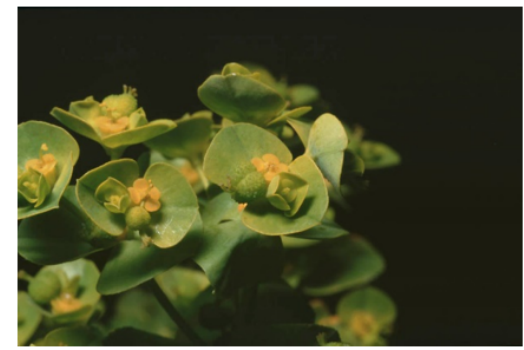

Euphorbia gaditana Coss. (Euphorbiaceae)
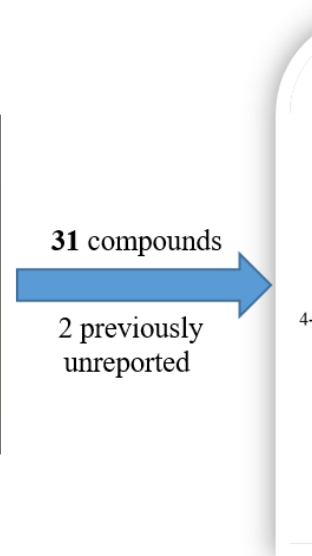

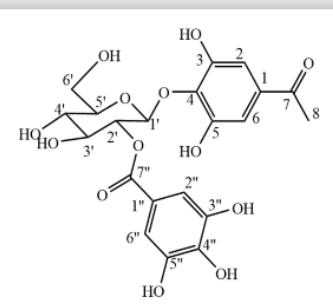

4-O-(2"-O-galloyl- $\beta$-D-glucopyranosyl)-3,5-dihydroxyacetophenone (1)

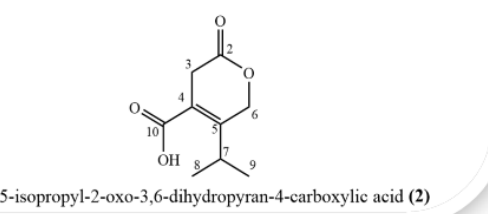

Tyrosinase activity

Compound 1: 89.78 $\pm 0.93 \mu \mathrm{g} / \mathrm{mL}$

Compound 2: $52.39 \pm 0.69 \mu \mathrm{g} / \mathrm{mL}$

Antioxidant activity:

DPPH, CUPRAC for all isolated compounds (1-31)

\section{Highlights}

- A phytochemical study of Euphorbia gaditana was carried out.

- Two previous unreported compounds type acetophenone and $\alpha$-pyrone, along with 29 known compounds were identified.

- An antioxidant activity-guided isolation was performed using DPPH and CUPRAC assays.

- All extracts and isolated compounds were evaluated for their antioxidant activity.

- The tyrosinase inhibitory activity was estimated for the two previous unreported molecules. 


\section{Antioxidant activity-guided isolation of constituents from Euphorbia gaditana Coss. and their antioxidant and tyrosinase inhibitory activities}

Mohamed Ibrahim Badaoui ${ }^{\mathrm{a}}$, Abdulmagid Alabdul Magid ${ }^{\mathrm{b}}$, Laurence VoutquenneNazabadioko $^{\mathrm{b}}$, Mohammed Benkhaled $^{\mathrm{a}}$, Dominique Harakat ${ }^{\mathrm{b}}$, Anthony Robert $^{\mathrm{b}}$ and Hamada Haba ${ }^{\mathrm{a}, *}$

${ }^{a}$ Laboratoire de Chimie et Chimie de l'Environnement (LCCE), Département de Chimie, Faculté des Sciences de la Matière, Université de Batna-1 05000, Algeria

${ }^{b}$ Université de Reims Champagne Ardenne, CNRS, ICMR UMR 7312, 51097 Reims, France

* Corresponding author: Hamada Haba Tel: +213 333190 15; Fax: +213 333190 15; E-mail address: haba.hamada@yahoo.fr; hamada.haba@univ-batna.dz 


\section{ABSTRACT}

Two previously unreported compounds, 4- $O$-(2"- $O$-galloyl- $\beta$-D-glucopyranosyl)-3,5dihydroxyacetophenone (1) and 5-isopropyl-2-oxo-3,6-dihydropyran-4-carboxylic acid (2), along with twenty-nine known compounds (3-31) were isolated from the aerial parts of Euphorbia gaditana Coss. Their structures were elucidated based on extensive spectroscopic analysis $1 \mathrm{D}$ and 2D-NMR, mass spectrometry HR-ESI-MS, optical rotation $[\alpha]_{\mathrm{D}}$, acid hydrolysis and the comparison of NMR data with those described in literature. The antioxidant activityguided study was conducted using DPPH and CUPRAC methods started from the extracts to bioactive isolated molecules. Most of the isolates (1-31) showed a good to excellent antioxidant activity compared to the standards BHT and ascorbic acid. Furthermore, $\mathbf{1}$ and $\mathbf{2}$ exhibited moderate tyrosinase inhibitory activity $\left(\mathrm{IC}_{50} 89.78 \pm 0.93\right.$ and $52.39 \pm 0.69 \mu \mathrm{g} / \mathrm{mL}$, respectively) compared to the standard kojic acid ( $\left.\mathrm{IC}_{50} 25.23 \pm 0.78 \mu \mathrm{g} / \mathrm{mL}\right)$.

Keywords: Euphorbiaceae; Euphorbia gaditana Coss.; 4-O-(2"-O-galloyl- $\beta$-D-glucopyranosyl)3,5-dihydroxyacetophenone; 5-isopropyl-2-oxo-3,6-dihydropyran-4-carboxylic acid; antioxidant activity; tyrosinase inhibitory activity

\section{Introduction}

The largest Euphorbia genus of the Euphorbiaceae family comprises about 2000 plants distributed worldwide. The species of this genus, from annuals to trees, are characterized by their latex (Shi et al., 2008). In the past years, a considerable attention has been paid to Euphorbia species due to their use in folk medicines to cure skin diseases, gonorrhea, migraines, intestinal parasites and as wart cures, and for their diverse pharmacological effects of their secondary 
metabolites, including antiproliferative, antimicrobial, antioxidant, antiviral and antiinflammatory activities (Benabdelaziz et al., 2018; Mouffouk et al., 2019; Özbilgin and Citoğlu, 2012; Shi et al., 2008; Singla and Pathak, 1990). This large range of pharmacological properties is due to a huge diversity of their chemical constituents such as diterpenes, triterpenes, sesquiterpenes, coumarins, phenols and flavonoids (Aichour et al., 2014; Benmerache et al., 2017; Haba et al., 2009; Haba et al., 2013; Özbilgin and Citoğlu, 2012; Liu et al., 2019).

Euphorbia gaditana Coss. is an annual plant grown in northern Algeria, Tunisia and southern Spain. Previously, the petroleum ether extract of E. gaditana has been studied and allowed the identification of two new diterpenes (Flores-Giubi et al., 2017). However, the present investigation is mainly focused on the EtOAc and $n-\mathrm{BuOH}$ extracts of this plant to discover other secondary metabolites particularly flavonoids and polyphenolic compounds following antioxidant activity-guided isolation.

We report in this paper chemical constitution of EtOAc and $n$-BuOH extracts, obtained from the $70 \%$ aqueous-ethanol extract of E. gaditana aerial parts, consisting of two previously unreported compounds, an acetophenone glycoside (1) and an $\alpha$-pyrone derivative (2), along with the previously described eighteen flavonoids (3-20) and eleven phenolic compounds (2131). In addition, the antioxidant capacity of the extracts of different solvents $\left(\mathrm{PE}, \mathrm{CHCl}_{3}, \mathrm{EtOAc}\right.$ and $n-\mathrm{BuOH}$ ), fractions and isolated compounds was evaluated using DPPH and CUPRAC methods. Furthermore, the tyrosinase inhibitory activity of all the extracts and $\mathbf{1}$ and $\mathbf{2}$ was investigated.

\section{Results and discussion}

\subsection{Phenolic and flavonoid contents}


The aerial parts of E. gaditana were macerated in $70 \%$ aqueous-ethanol and the obtained extract was fractionated by liquid-liquid partition, with petroleum ether, chloroform, ethyl acetate, and $n$-butanol. The obtained extracts i.e. $\mathrm{PE}, \mathrm{CHCl}_{3}$, EtOAc and $n$-BuOH were investigated for their total phenolic and flavonoid contents (TPC, TFC). The results of TPC are expressed by gallic acid equivalent (GAE) as (mg GAE/g Extract), and those of TFC are given by quercetin equivalent $(\mathrm{QE})$ as (mg $\mathrm{QE} / \mathrm{g}$ Extract) (Table 1). Indeed, the most rich extract in flavonoids was the EtOAc extract $(91.31 \pm 1.35 \mathrm{mg} \mathrm{QE} / \mathrm{g})$, followed by the $n$-BuOH extract $(37.16 \pm 2.40 \mathrm{mg} \mathrm{QE} / \mathrm{g})$, and then $\mathrm{CHCl}_{3}$ and $\mathrm{PE}$ extracts $(11.70 \pm 1.51$ and $1.17 \pm 0.25 \mathrm{mg}$ $\mathrm{QE} / \mathrm{g}$, respectively). In addition, the determination of total phenolic contents indicated that the EtOAc extract has the highest content of phenolic compounds (189.87 $\pm 1.32 \mathrm{mg} \mathrm{GAE} / \mathrm{g})$ even more than the $n-\mathrm{BuOH}$ extract $(109.26 \pm 1.43 \mathrm{mg} \mathrm{GAE} / \mathrm{g})$. However, the $\mathrm{CHCl}_{3}$ and PE extracts yielded low phenolic contents $(29.39 \pm 1.98$ and $6.32 \pm 1.43 \mathrm{mg} \mathrm{GAE} / \mathrm{g}$, respectively) (Table 1).

\section{Insert table 1 here}

\subsection{Chemical constituents}

The EtOAc and $n-\mathrm{BuOH}$ extracts were chosen for further purification based on their total phenolic contents, antioxidant activity, TLC and HPLC profiles. The purification of EtOAc and $n$-BuOH extracts using different chromatographic methods (VLC, CC, TLC, MPLC, and HPLC) afforded thirty-one compounds. All the structures were elucidated based on 1D, 2D-NMR, (-) and (+)-HR-ESI-MS techniques and the measurement of optical rotation. Besides, the NMR data of previously described compounds (3-29) were compared with those reported in the literature.

The previously unreported compounds were elucidated as 4-O-(2"-O-galloyl- $\beta$-Dglucopyranosyl)-3,5-dihydroxyacetophenone (1) and 5-isopropyl-2-oxo-3,6-dihydropyran-4carboxylic acid (2) (Fig. 1), whereas the known compounds have been identified as (-) catechin 
(3) (Son et al., 1989), quercetin (4) (Chang et al., 2009), myricetin (5) (Sakushima et al., 1983), 3-O- $\beta$-D-glucopyranosyl quercetin (6) (Chang et al., 2009), 3-O- $\alpha$-L-arabinopyranosyl kaempferol (7) (Cui et al., 2018), 3-O- $\alpha$-L-arabinopyranosyl quercetin (8), 3-O- $\alpha$-Larabinopyranosyl myricetin (9) (El-Toumy et al., 2010), 3-O- $\alpha$-L-rhamnopyranosyl quercetin (10) (Chang et al., 2009), 3-O- $\alpha$-L-rhamnopyranosyl myricetin (11) (El-Toumy et al., 2010), 3$O-\beta$-D-glucuronopyranosyl kaempferol (12) (Satake et al., 2007), 3- $O$-(6"- $O$-methyl- $\beta$-Dglucuronopyranosyl) kaempferol (13) (Zaghloul, 1993), 3-O- $\beta$-D-glucuronopyranosyl quercetin (14) (Satake et al., 2007), 3-O- $\beta$-D-glucuronopyranosyl myricetin (15) (Hilbert et al., 2014), 3-O(6"-O-methyl- $\beta$-D-glucuronopyranosyl) myricetin (16) (Gomaa-Darwish et al., 2016), 3-O-(2"$O$-galloyl- $\alpha$-L-rhamnopyranosyl) quercetin (17) (Isobe et al., 1981), 3-O-(3"-O-galloyl- $\alpha$-Lrhamnopyranosyl) quercetin (18) (Lin et al., 2002), 3-O-(2"-O-galloyl- $\alpha$-L-rhamnopyranosyl) myricetin (19) (Lee et al., 2017), 3-O-(3"-O-galloyl- $\alpha$-L-rhamnopyranosyl) myricetin (20) (sun et al., 1991), trilobatin (21) (Dugé de Bernonville et al., 2009), citrusin E (22) (Matsubara et al., 1991), (Z)-p-coumaroyl-1-O- $\beta$-D-glucopyranoside (23) (Fons et al., 1998), 3,5dihydroxyacetophenone-4- $O$ - $\beta$-D-glucopyranoside (24) (Cho et al., 2013), 4- $O$-caffeoylquinic acid methyl ester (25) (Zhu et al., 2005), 4- $O$-feruloylquinic acid methyl ester (26) (Li et al., 1998), chlorogenic acid (27) (Satake et al., 2007), 5-O-feruloylquinic acid methyl ester (28) (Menozzi Smarrito et al., 2008), 3,4,5-trihydroxyacetophenone (29) (Li and Seeram, 2011), ethyl gallate (30) (Chen et al., 2018), and (Z)-p-coumaric acid (31) (Swisłocka et al., 2012) (Fig. S1).

\subsection{Structure elucidation of 1 and $\mathbf{2}$}

Compound $\mathbf{1}$ was isolated as a brown amorphous powder. The (+)-HR-ESI-MS showed a pseudomolecular ion peak at $\mathrm{m} / \mathrm{z} 505.0953[\mathrm{M}+\mathrm{Na}]^{+}\left(\right.$calcd $\left.\mathrm{C}_{21} \mathrm{H}_{22} \mathrm{O}_{13} \mathrm{Na}, 505.0958\right)$, which 
corresponded to the molecular formula $\mathrm{C}_{21} \mathrm{H}_{22} \mathrm{O}_{13}$ requiring 11 degrees of unsaturation. The UV spectrum of 1 exhibited maxima absorption bands at 220 and $278 \mathrm{~nm}$ revealing the presence of a phenolic derivative (Jancovicova et al., 2007). The ${ }^{1} \mathrm{H}-\mathrm{NMR}$ spectrum (Table 2) displayed signals for a methyl group at $\delta_{\mathrm{H}} 2.60(3 \mathrm{H}, \mathrm{s})$, and four aromatic protons belonging to two symmetrical 1,3,4,5-tetrasubstituted benzene rings at $\delta_{\mathrm{H}} 5.98(2 \mathrm{H}, \mathrm{s}, \mathrm{H}-2 / \mathrm{H}-6)$ and $7.07(2 \mathrm{H}, \mathrm{s}$, $\left.\mathrm{H}-2^{\prime \prime} / \mathrm{H}-6^{\prime \prime}\right)$, respectively. A signal of an anomeric proton at $\delta_{\mathrm{H}} 5.21(1 \mathrm{H}, \mathrm{d}, J=8.1 \mathrm{~Hz})$, with a signal at $\delta_{\mathrm{H}} 5.12(1 \mathrm{H}, \mathrm{dd}, J=9.5,8.1 \mathrm{~Hz})$ and other protons in the range $(3.5-4.0 \mathrm{ppm})$ coupled with the correlations observed in the ${ }^{1} \mathrm{H}-{ }^{1} \mathrm{H}-\mathrm{COSY}$ spectrum (Figs. S6 and S7) and the large coupling constants between $\mathrm{H}-1^{\prime} / \mathrm{H}-2^{\prime}, \mathrm{H}-2^{\prime} / \mathrm{H}-3^{\prime}, \mathrm{H}-3^{\prime} / \mathrm{H}-4^{\prime}$ and $\mathrm{H}-4^{\prime} / \mathrm{H}-5^{\prime}$ indicated the presence of $\beta$-glucopyranosyl moiety. These structural features suggested $\mathbf{1}$ to be an acetophenone glucoside (Cho et al., 2013; Huang et al., 2017). The HSQC correlations allowed evidently the assignment of the protons at $\delta_{\mathrm{H}} 2.60,3.53,3.74,3.77,3.96,5.12,5.98$ and 7.07 attached to the carbons at $\delta_{\mathrm{C}} 33.0(\mathrm{C}-8), 71.6\left(\mathrm{C}-4^{\prime}\right), 78.5\left(\mathrm{C}-5^{\prime}\right), 76.1\left(\mathrm{C}-3^{\prime}\right), 62.3\left(\mathrm{C}-6^{\prime}\right), 74.9\left(\mathrm{C}-2^{\prime}\right), 99.7(\mathrm{C}-$ 1'), 96.3 (C-2 and C-6) and 110.3 (C-2" and C-6") respectively. In addition to these carbons, the ${ }^{13} \mathrm{C}-\mathrm{NMR}$ spectrum (Table 2) exhibited two signals at $\delta_{\mathrm{C}} 107.3(\mathrm{C}-1)$ and $121.3\left(\mathrm{C}-1{ }^{\prime \prime}\right)$ ascribable to non-protonated aromatic carbons, and four signals of oxygenated aromatic carbons at $\delta_{\mathrm{C}} 140.0$ (C-4"), 146.5 (C-3", C-5"), 164.9 (C-4), and 165.5 (C-3, C-5). The non-protonated sp ${ }^{2}$ carbon signal resonating at $167.6 \mathrm{ppm}$ was attributed to a conjugated carbonyl group (C-7"), whereas another carbonyl signal at $\delta_{\mathrm{C}} 205.3$ (C-7) suggested the presence of a ketone functionality. The HMBC spectrum showed a correlation from $\mathrm{H}-1^{\prime}$ to $\mathrm{C}-4$ suggesting that the $\beta$-glucopyranosyl moiety is linked to $\mathrm{C}-4$ via an oxygen bridge. Moreover, $\mathrm{H}-2^{\prime}$ and $\mathrm{H}-2^{\prime \prime} / \mathrm{H}-6^{\prime \prime}$ also displayed HMBC correlations to $\mathrm{C}-7^{\prime \prime}$, indicating that $\mathrm{C}-2^{\prime}$ of the $\beta$-glucopyranosyl moiety is linked to $\mathrm{C}$ 7" of the galloyl moiety through an ester linkage. Furthermore, the HMBC spectrum presented 
cross-peaks from $\mathrm{H}-2 / \mathrm{H}-6$ and $\mathrm{H}_{3}-8$ to $\mathrm{C}-7$ supporting the presence of a function ketone on $\mathrm{C}-7$ (Fig. S12). The NOESY spectrum displayed correlation from $\mathrm{H}-2 / \mathrm{H}-6$ to $\mathrm{H}_{3}-8$, thus confirming the structure of $\mathbf{1}$. Based on the above evidence and comparison of the NMR data of $\mathbf{1}$ with those of the previously isolated analogue (Huang et al., 2017), 1 was elucidated as 4-O-(2"-O-galloyl$\beta$-D-glucopyranosyl)-3,5-dihydroxyacetophenone, and was named gadiacetophenone.

\section{Insert fig. 1 here}

Compound 2 was isolated as white crystal. The (+)-HR-ESI-MS spectrum displayed a pseudomolecular ion peak at $\mathrm{m} / z$ 207.0628 $[\mathrm{M}+\mathrm{Na}]^{+}$(calcd $\mathrm{C}_{9} \mathrm{H}_{12} \mathrm{O}_{4} \mathrm{Na}, 207.0633$ ) corresponding to the molecular formula $\mathrm{C}_{9} \mathrm{H}_{12} \mathrm{O}_{4}$, indicating that the molecule possessed four degrees of unsaturation. The IR spectrum indicated absorption bands at $3451 \mathrm{~cm}^{-1}(\mathrm{OH})$, $1752 \mathrm{~cm}^{-1}$ (pyrone carbonyl), $1690 \mathrm{~cm}^{-1}$ (carbonyl acid), and $1645 \mathrm{~cm}^{-1}$ (double bond). The ${ }^{1} \mathrm{H}-$ NMR spectrum (Table 2) showed signals at $\delta_{\mathrm{H}} 1.09\left(6 \mathrm{H}, \mathrm{d}, J=7.0 \mathrm{~Hz}, \mathrm{CH}_{3}-8, \mathrm{CH}_{3}-9\right), 3.33(2 \mathrm{H}$, t, $J=1.8 \mathrm{~Hz}, \mathrm{H}-3), 4.95(2 \mathrm{H}, \mathrm{t}, J=1.8 \mathrm{~Hz}, \mathrm{H}-6)$ and $3.87(1 \mathrm{H}, \mathrm{m}, \mathrm{H}-7)$. The ${ }^{1} \mathrm{H}-{ }^{1} \mathrm{H}-\mathrm{COSY}$ spectrum revealed correlations from the doublet at $\delta_{\mathrm{H}} 1.09$ to $\mathrm{H}-7$ suggesting the presence of an isopropyl group. The ${ }^{13} \mathrm{C}-\mathrm{NMR}$ spectrum (Table 2) exhibited signals corresponding to nine carbon atoms including five $\mathrm{sp}^{3}$ at $\delta_{\mathrm{C}} 20.1(\mathrm{C}-8, \mathrm{C}-9), 29.8(\mathrm{C}-7), 32.8(\mathrm{C}-3)$ and $68.2(\mathrm{C}-6)$, two non-protonated $\mathrm{sp}^{2}$ at $\delta_{\mathrm{C}} 121.0(\mathrm{C}-4)$ and $152.8(\mathrm{C}-5)$ and two carbonyls at $\delta_{\mathrm{C}} 168.1(\mathrm{C}-10)$ and $173.3(\mathrm{C}-2)$. In addition, the HSQC spectrum allowed the assignment of the methyl protons at $\delta_{\mathrm{H}}$ 1.09 to $\mathrm{C}-8$ and $\mathrm{C}-9$, the methylene protons at $\delta_{\mathrm{H}} 3.33$ to the carbon at $32.8(\mathrm{C}-3)$, the methine proton at $\delta_{\mathrm{H}} 3.87$ to the carbon at $\delta_{\mathrm{C}} 29.8(\mathrm{C}-7)$ and the oxymethylene protons at $\delta_{\mathrm{H}} 4.95$ to the carbon at 68.2 (C-6). The HMBC spectrum also showed correlations from $\mathrm{H}_{3}-8$ and $\mathrm{H}_{3}-9$ to $\mathrm{C}-7$ and C-5, H-7 to C-8, C-9, C-6, C-4 and C-5, $\mathrm{H}_{2}-3$ to C-4, C-5, C-10 and C-2, and $\mathrm{H}_{2}-6$ to C-4, C5 and C-2 (Figs. S22 and S23). These spectroscopic features suggested that $\mathbf{2}$ is a derivative of $\alpha$ - 
pyrone (Onocha et al., 1995) with a carboxylic acid functionality. Due to the previous HMBC correlations from $\mathrm{H}_{3}-8$ and $\mathrm{H}_{3}-9$ to $\mathrm{C}-5$ and $\mathrm{H}-7$ to $\mathrm{C}-4$, and NOESY effects observed between $\mathrm{H}_{3}-8 / \mathrm{H}_{3}-9$ and $\mathrm{H}_{2}-6$, the isopropyl group and the carboxylic acid functionality are linked to ethylenic carbons C-5 and C-4, respectively (Figs. S20 and S23). All the above data were consistent with the structure of $\mathbf{2}$ which was characterized as 5-isopropyl-2-oxo-3,6dihydropyran-4-carboxylic acid and named gadipyrone.

Several plants revealed the presence of $\alpha$-pyrone derivatives with different skeletons such as monocyclic $\alpha$-pyrone (e.g., djalonenol, boronolide, deacetylboronolide) (Onocha et al., 1995; Davies-Coleman et al., 1987), monobenzo-a-pyrone (e.g., aesculetin, fraxin) (Liu et al., 2005), dibenzo- $\alpha$-pyrone (e.g., autumnariol, sarolactone, 3-epialtenuene) (Mao et al., 2014) or a moiety of a complex structure (e.g., cryptorigidifoliol F, cryptorigidifoliol I) (Liu et al., 2015). Compound $\mathbf{2}$ is the first example of $\alpha$-pyrone possessing a double bond between C-4 and C-5, which might be biosynthesized via the pathways involved in the biosynthesis of $\alpha$-pyrone such as the $\beta$-oxidation of linoleic acid and the condensation of malonyl-CoA derivatives in polyketide synthase (Schäberle 2016). Hence, gadipyrone (2) could be of importance for the elucidation of biogenesis of $\alpha$-pyrone.

\section{Insert table 2 here}

\subsubsection{Identification of D-glucose}

The acid hydrolysis of $\mathbf{1}$ was carried to establish the configuration of the monosaccharide residue. $10 \mathrm{mg}$ of 1 was refluxed with $5 \mathrm{~mL}$ of $2 \mathrm{~N} \mathrm{HCl}$ for $4 \mathrm{~h}$, and then neutralized with $0.5 \mathrm{M}$ $\mathrm{KOH}$. After extraction with $\mathrm{CH}_{2} \mathrm{Cl}_{2}(3 \times 5 \mathrm{~mL})$, the aqueous solution was evaporated to get D- 
glucose $\left(1.6 \mathrm{mg},[\alpha]^{20}{ }_{\mathrm{D}}+25.8^{\circ}\left(\mathrm{c} 0.11, \mathrm{H}_{2} \mathrm{O}\right)\right.$ (Budavari et al., 1989), which was confirmed by TLC comparison with an authentic sample.

\subsection{Biological studies}

The phytochemical investigation of E. gaditana afforded numerous secondary metabolites especially flavonoids and phenolics from the AcOEt and $n$ - $\mathrm{BuOH}$ extracts, which is compatible with the TFC and TPC measurements. It's well known that natural polyphenol compounds furnished a good antioxidant activity (Badaoui et al., 2019; Mouffouk et al., 2019; Rice-Evans et al., 1996). For this reason, and in order to isolate bioactive compounds, an antioxidant activityguided isolation has been conducted. The antioxidant capacity of all the extracts has been evaluated using DPPH and CUPRAC methods. The EtOAc and $n$-BuOH extracts have been selected for a phytochemical and biological study, due to their richness in polyphenolic compounds and according to their antioxidant capacity (DPPH IC $\mathrm{I}_{50} 8.28 \pm 0.88$ and $11.23 \pm 0.66$ $\mu \mathrm{g} / \mathrm{mL}$; CUPRAC A $0.56 .44 \pm 1.09$ and $15.94 \pm 1.07 \mu \mathrm{g} / \mathrm{mL}$, respectively). Furthermore, each extract was fractionated, and the major fractions obtained were tested using DPPH and CUPRAC assays. Fractions Ac1, Ac2, Ac3, Bu1, Bu2 and Bu3 have been chosen for chromatographic purifications based on their $\mathrm{IC}_{50}$ and $\mathrm{A}_{0.5}$ values (Table 3).

\section{Insert table 3 here}

The selected fractions were subjected to a phytochemical investigation and 31 compounds were isolated and tested for their antioxidant capacity by DPPH and CUPRAC methods. Compound 1 exhibited an excellent antioxidant activity (DPPH IC $503.25 \pm 0.09 \mu \mathrm{g} / \mathrm{mL}$, CUPRAC $\mathrm{A}_{0.5} 7.09 \pm 0.1 \mu \mathrm{g} / \mathrm{mL}$ ) compared to the standards BHT and ascorbic acid (DPPH IC $\mathrm{I}_{50}$ $12.99 \pm 0.41$ and $13.94 \pm 2.81 \mu \mathrm{g} / \mathrm{mL} ;$ CUPRAC $\mathrm{A}_{0.5} 8.97 \pm 3.94$ and $52.59 \pm 1.98 \mu \mathrm{g} / \mathrm{mL}$, 
respectively). Compound 2 was not active at the tested concentration $(200 \mu \mathrm{g} / \mathrm{mL})$. In addition, the majority of the known compounds (3-31) indicated good to excellent antioxidant activity (Table 3).

The number and a structural variation of the isolated flavonoids lead us to study the relationship structure-activity. Quercetin (4) gave a higher antioxidant activity than myricetin (5); so, we conclude that the third hydroxyl group in B ring of the flavonol decreases the antioxidant capacity (Fig. S1). Moreover, the type of sugar on C-3 of flavonols also affects the antioxidant activity. Comparing the effect of sugars on $\mathrm{C}-3$ on the antioxidant activity of $\mathbf{6 , 8 , 1 0}$ and 14, it was found that the antioxidant activity decreases from arabinose to glucose, from glucose to rhamnose and from rhamnose to glucuronic acid. This effect is corroborated by the antioxidant capacity observed for 9, 11 and 15. Comparison of 12 with 13 , and 15 with 16 revealed that glucuronic acid displays a higher activity than its methyl ester. Furthermore, the comparison of 17 and 18 with 10, and of 19 and 20 with 11, indicated that the addition of the galloyl group to rhamnose of the 3-O-rhamnosyl flavonoids increases their antioxidant activity, especially when the galloyl group is linked to C-3 instead of C-2 of rhamnose (Table 3).

The tyrosinase activity (Table 3) was also evaluated for the extracts, major fractions as well as for $\mathbf{1}$ and $\mathbf{2}$. Indeed, $\mathbf{1}$ and $\mathbf{2}$ displayed moderate tyrosinase inhibitory activity with $\mathrm{IC}_{50}$ values of $89.78 \pm 0.93$ and $52.39 \pm 0.69 \mu \mathrm{g} / \mathrm{mL}$, respectively, when compared to kojic acid $\left(\mathrm{IC}_{50}=25.23\right.$ $\pm 0.78 \mu \mathrm{g} / \mathrm{mL})$.

\section{Conclusion}

In summary, two previously undescribed compounds named gadiacetophenone (1) and gadipyrone (2), along with twenty-nine previously reported compounds (3-31), comprising 
seventeen flavonoids and eleven phenolic compounds, were isolated and identified from the aerial parts of Euphorbia gaditana Coss. Among the known constituents, thirteen compounds (9, 15-22, 24-26 and 28) possessing several skeletons like flavonol, acetophenone glycoside, hydroxycinnamic acid glycoside and chlorogenic acid, are found for the first time in Euphorbia species. The antioxidant activity, evaluated by DPPH and CUPRAC methods for extracts, fractions and all the isolated compounds showed in general good to excellent antioxidant activity. Furthermore, the two undescribed compounds $\mathbf{1}$ and $\mathbf{2}$ showed a moderate inhibition of the tyrosinase enzyme comparing to the standard kojic acid.

\section{Experimental}

\subsection{General experimental procedures}

UV spectra were measured on a Shimadzu UV/Vis U-2450 spectrophotometer. IR spectra were obtained using a Nicolet Impact 410 FTIR spectrometer. Optical rotations were measured on a Perkin-Elmer 341 polarimeter. 1D and 2D-NMR spectra were recorded in $\mathrm{CH}_{3} \mathrm{OH}-d_{4}$ on Bruker Avance DRX III 500 instrument using standard Bruker microprograms (Karlsruhe, Germany). (-) and (+)-HR-ESI-MS were obtained from Micromass Q-TOF micro-instrument (Manchester, UK). Flash chromatography was performed on a Grace Reveleris system equipped with dual UV and ELSD detection using Grace cartridges (Silica gel or RP- $\mathrm{C}_{18}$ ), and the monitored wavelengths were at 205 and $254 \mathrm{~nm}$. The medium-pressure liquid chromatography (MPLC) was employed using a Buchi pump system AP250/500 (Bushi, France), with a RP-C 18 silica gel MERCK column $(15 \times 230$ and $26 \times 460$ mm). Preparative HPLC (PLC 2050 Gilson) was equipped with a RP-C 18 column (Phenomenex 250 -15 mm, Luna $5 \mathrm{~m}$, Interchim, France), it was used as a semi-preparative HPLC with a binary gradient eluent $\left(\mathrm{H}_{2} \mathrm{O}\right.$ pH 2.4 with TFA; 
$\mathrm{CH}_{3} \mathrm{CN}$ ) and a flow rate of $5 \mathrm{~mL} / \mathrm{min}$; the chromatogram was monitored at 205, 254, 300, and $360 \mathrm{~nm}$. Semi-preparative HPLC was performed on an apparatus equipped with an ASI-100 Dionex autosampler, an Ultimate 3000 pump ThermoFisher Scientific, a diode array detector UVD 340S and a Chromeleon software (Dionex, ThermoFisher Scientific, France). RP-C 18 column (Phenomenex 250 -15 mm, Luna $5 \mathrm{~m}$, Interchim, France) was used for a semipreparative $\mathrm{HPLC}$ with a binary gradient eluent $\left(\mathrm{H}_{2} \mathrm{O} \mathrm{pH} 2.4\right.$ with TFA; $\left.\mathrm{CH}_{3} \mathrm{CN}\right)$ and a flow rate of $5 \mathrm{~mL} / \mathrm{min}$; the chromatogram was monitored at 205, 254, 300, and $360 \mathrm{~nm}$. An HPLC analytic Ultimate 3000 ThermoFisher Scientific equipped with LPG 3400SD pump, WPS3000SL injector, UV-DAD-3000 detector (ThermoFisher Scientific, France); and an Interchim uptisphere strategy column C-18-HQ $250 \times 4.6 \mathrm{~mm}$ (Interchim, France) was used. Analytical TLC was performed using silica gel plates (Merck Kieselgel 60 F254) and RP-C 18 (Kieselgel 60 F254S) plates and visualized at 254 and $366 \mathrm{~nm}$ and by spraying the dried plates with $50 \%$ of $\mathrm{H}_{2} \mathrm{SO}_{4}$, followed by heating.

The bioactivity assays were carried out at the Center of biotechnology Research (Algeria) on a 96-well microplate reader, Perkin Elmer Multimode Plate Reader EnSpire (Perkin Elmer, France). Folin-Ciocalteu reagent (FCR), 1,1-diphenyl-2-picrylhydrazyl (DPPH), butylated hydroxytoluene (BHT), ascorbic acid, ammonium acetate were obtained from Sigma Chemical Co. (Sigma-Aldrich GmbH, Sternheim, Germany). Copper (II) chloride, neocuproine, L-DOPA and tyrosinase enzyme were purchased from Biochem Chemopharma (Biochem Chemopharma, France). All other chemicals and solvents were of analytical grade.

\subsection{Plant material}


The plant Euphorbia gaditana Coss. was collected in May 2015 in Seriana from semi-arid region of Batna (North eastern of Algeria). It was identified by Prof. Bachir Oudjehih from the Agronomic Institute of the University of Batna-1 (Algeria). A voucher specimen number (908/ LCCE) was deposited at the Faculty of Sciences of Matter, University of Batna-1, Algeria.

\subsection{Extraction and isolation}

The aerial parts of E. gaditana (1 kg of dried powder) were macerated in $70 \%$ aqueousethanol $(2 \times 12 \mathrm{~L}, 48 \mathrm{~h})$ at room temperature, and then filtered by filter paper and the aqueousethanol solution was concentrated under reduced pressure to remove EtOH. The aqueous solution was successively extracted with $\mathrm{PE}(3 \times 300 \mathrm{~mL}), \mathrm{CHCl}_{3}(3 \times 300 \mathrm{~mL}), \mathrm{EtOAc}(3 \times 300$ $\mathrm{mL})$ and $n$-BuOH $(3 \times 300 \mathrm{~mL})$. The obtained organic phases were evaporated to dryness under reduced pressure at $45^{\circ} \mathrm{C}$ to provide $1.3 \mathrm{~g}$ of PE, $30 \mathrm{~g}$ of $\mathrm{CHCl}_{3}, 7.1 \mathrm{~g}$ of EtOAc and $23.1 \mathrm{~g}$ of $n$ $\mathrm{BuOH}$ extracts. All the extracts and fractions were stored in darkness at room temperature before fractionation and purification. The EtOAc and $n-\mathrm{BuOH}$ extracts were chosen for further purification based on their antioxidant activity, TLC and HPLC profiles.

The EtOAc extract (7.1 g) was subjected to vacuum liquid chromatography (VLC) over RP$\mathrm{C}_{18}$ and eluted successively with $\left(20,40,60,80\right.$, and $100 \% \mathrm{MeOH}$ in $\mathrm{H}_{2} \mathrm{O}, 1 \mathrm{~L}$ each) to provide five major fractions (Ac1-Ac5). Ac1 (2.2 g) was applied to a flash chromatography of silica gel and eluted with mixtures of $\mathrm{CH}_{2} \mathrm{Cl}_{2}-\mathrm{MeOH}-\mathrm{H}_{2} \mathrm{O}$ (10:0:0-7:3:0-70:30:5) to obtain fraction Ac1-E (195 mg) which was further purified by flash chromatography over RP-C 18 and eluted with $\mathrm{MeOH}-\mathrm{H}_{2} \mathrm{O}(5-20 \% \mathrm{MeOH})$ to yield $3(19.4 \mathrm{mg})$. Fraction Ac2 (2 g) was fractionated by preparative HPLC over RP-C $\mathrm{C}_{18}$. The elution was carried out by $\mathrm{CH}_{3} \mathrm{CN}-\mathrm{H}_{2} \mathrm{O}\left(20-30 \% \mathrm{CH}_{3} \mathrm{CN}\right.$, in $45 \mathrm{~min}$ ) to obtain fractions Ac2-C (144 mg), Ac2-D (192), Ac2-E (356 mg), Ac2-F (268 mg), 
Ac2-G (157 mg) and Ac2-H (100 mg); then, fractions (Ac2-C, Ac2-D, Ac2-E, Ac2-G and Ac2$\mathrm{H}$ ) were purified by flash chromatography of a silica gel and eluted with $\mathrm{CH}_{2} \mathrm{Cl}_{2}-\mathrm{MeOH}-\mathrm{H}_{2} \mathrm{O}$ (100:0:0-70:30:0-70:30:5). Indeed, fraction Ac2-C provided compounds 9 (10 mg) and 24 (7 $\mathrm{mg}$ ), fraction Ac2-D gave compound $\mathbf{5}(5.8 \mathrm{mg})$, fraction Ac2-E afforded compound $\mathbf{3 0}$ (43.5 $\mathrm{mg}$ ) and sub-fraction Ac2-E-g (34 mg) which was further purified using preparative HPLC to yield $6(2.5 \mathrm{mg})$, and fraction Ac2-G provided compounds $2(5.8 \mathrm{mg})$ and $\mathbf{3 1}(7 \mathrm{mg})$, whereas, fraction Ac2-H furnished $29(2.5 \mathrm{mg})$. Fraction Ac2-F was purified by flash chromatography of silica gel and eluted with $\mathrm{CH}_{2} \mathrm{Cl}_{2}-\mathrm{MeOH}(0-35 \% \mathrm{MeOH}, 30 \mathrm{~min})$ to afford sub-fraction Ac2-F-k (141 mg), which was purified by preparative HPLC using $\mathrm{CH}_{3} \mathrm{CN}-\mathrm{H}_{2} \mathrm{O}$ as eluent (20-35\% $\left.\mathrm{CH}_{3} \mathrm{CN}, 30 \mathrm{~min}\right)$ to furnish $1(5.8 \mathrm{mg})$. Fraction Ac3 was subjected to preparative HPLC over RP- $\mathrm{C}_{18}$ and eluted with $\mathrm{CH}_{3} \mathrm{CN}-\mathrm{H}_{2} \mathrm{O}\left(20-35 \% \mathrm{CH}_{3} \mathrm{CN}, 30 \mathrm{~min}\right)$ to obtain $4(7 \mathrm{mg}), 8(19.6 \mathrm{mg})$, 10 (24 mg), 11 (6.7 mg), 17 (17.5 mg), in addition to sub-fractions Ac3-24 (27 mg), Ac3-26 (18 $\mathrm{mg}$ ) and Ac3-31 (18 mg). These sub-fractions were further purified with semi-preparative HPLC using $\mathrm{CH}_{3} \mathrm{CN}-\mathrm{H}_{2} \mathrm{O}$ as eluent $\left(20-35 \% \mathrm{CH}_{3} \mathrm{CN}\right)$ to yield $\mathbf{1 9}\left(3.8 \mathrm{mg}, t_{\mathrm{R}} 3.05 \mathrm{~min}\right)$ and $\mathbf{2 0}(2.6 \mathrm{mg}$, $t_{\mathrm{R}} 11.52 \mathrm{~min}$ ) from sub-fraction Ac3-24; 21 (3 mg, $\left.t_{\mathrm{R}} 26.55 \mathrm{~min}\right)$ from sub-fraction Ac3-26 and $18\left(2.5 \mathrm{mg}, t_{\mathrm{R}} 22.10 \mathrm{~min}\right)$ from sub-fraction Ac3-31.

The $n$ - $\mathrm{BuOH}$ extract (22 g) was applied to VLC over RP-C 18 . The elution was performed with $\mathrm{MeOH}-\mathrm{H}_{2} \mathrm{O}(0: 100-100: 0)$ to afford six fractions (Bu0-Bu5). Fraction Bu1 (3.4 g) was fractionated by flash chromatography over $\mathrm{RP}^{-\mathrm{C}_{18}}$ and eluted with $\mathrm{MeOH}-\mathrm{H}_{2} \mathrm{O}(5-40 \% \mathrm{MeOH}$, $30 \mathrm{~min})$ to obtain $27(17 \mathrm{mg})$ and several sub-fractions. Sub-fractions Bu1-C and Bu1-D were combined (64 mg) and purified by semi-preparative HPLC using $\mathrm{CH}_{3} \mathrm{CN}-\mathrm{H}_{2} \mathrm{O}$ as eluent $(5-25 \%$ MeCN, $30 \mathrm{~min}$ ) to yield $23\left(1.5 \mathrm{mg}, t_{\mathrm{R}} 25.03 \mathrm{~min}\right)$. Sub-fraction Bu1-Q (316 mg) was purified by flash chromatography over silica gel and eluted with $\mathrm{CH}_{2} \mathrm{Cl}_{2}-\mathrm{MeOH}-\mathrm{H}_{2} \mathrm{O}$ (100:0:0-70:30:0- 
70:30:5) to give two sub-fractions Bu1-Q-c and Bu1-Q-d. Bu1-Q-c (27 mg) was further purified by semi-preparative HPLC eluting with $\mathrm{MeCN}-\mathrm{H}_{2} \mathrm{O}\left(17-21 \% \mathrm{CH}_{3} \mathrm{CN}, 25 \mathrm{~min}\right)$ to afford 25 (5.5 $\left.\mathrm{mg}, t_{\mathrm{R}} 8.25 \mathrm{~min}\right)$ and $22\left(3 \mathrm{mg}, t_{\mathrm{R}} 11.54 \mathrm{~min}\right)$. Sub-fraction Bu1-Q-d $(10.5 \mathrm{mg})$ gave, after precipitation in $\mathrm{MeOH}, 28(7.7 \mathrm{mg})$. Fraction $\mathrm{Bu} 2(5.3 \mathrm{~g})$ was purified by flash chromatography of a silica gel and eluted with $\mathrm{CH}_{2} \mathrm{Cl}_{2}-\mathrm{MeOH}-\mathrm{H}_{2} \mathrm{O}$ (100:0:0-70:30:0-70:30:5) to provide several sub-fractions. Sub-fraction Bu2-C (11.3 mg) was purified by preparative HPLC (15-35\% $\left.\mathrm{CH}_{3} \mathrm{CN}, 30 \mathrm{~min}\right)$ to give $26(2.6 \mathrm{mg})$. Sub-fraction $\mathrm{Bu} 2-\mathrm{E}(600 \mathrm{mg})$ was applied to flash chromatography of RP-C 18 and eluted with $\mathrm{MeOH}-\mathrm{H}_{2} \mathrm{O}(15-25 \% \mathrm{MeOH}, 30 \mathrm{~min})$ to afford subfraction Bu2-E-h $(68 \mathrm{mg})$ which was purified by semi-preparative HPLC over RP-C 18 using $\mathrm{CH}_{3} \mathrm{CN}-\mathrm{H}_{2} \mathrm{O}$ as eluent (15-25\%) to furnish 16 (44 mg, $\left.t_{\mathrm{R}} 12.13 \mathrm{~min}\right)$. Sub-fraction Bu2-J (80 mg) was purified by preparative HPLC and eluted with $\mathrm{CH}_{3} \mathrm{CN}-\mathrm{H}_{2} \mathrm{O}\left(15-35 \mathrm{CH}_{3} \mathrm{CN}, 30 \mathrm{~min}\right)$ to give 15 (6 mg). Fraction Bu3 (2.6 g) was chromatographed over flash chromatography of silica gel. The elution was carried out with $\mathrm{CH}_{2} \mathrm{Cl}_{2}-\mathrm{MeOH}-\mathrm{H}_{2} \mathrm{O}$ (100:0:0-70:30:0-70:30:5) to provide two sub-fractions Bu3-I (20 mg) and Bu3-R $(84 \mathrm{mg})$ which were purified by preparative HPLC using $\mathrm{CH}_{3} \mathrm{CN}-\mathrm{H}_{2} \mathrm{O}$ as eluent $\left(25-45 \% \mathrm{CH}_{3} \mathrm{CN}\right)$ and $\left(15-25 \% \mathrm{CH}_{3} \mathrm{CN}\right)$, respectively, to yield $7(1.3 \mathrm{mg})$ and 13 (1mg) from sub fraction Bu3-I, and $12(5.4 \mathrm{mg})$ and $\mathbf{1 4}(7.3 \mathrm{mg})$ from sub-fraction Bu3R.

\subsubsection{Spectral data}

Gadiacetophenone (4-O-(2"-O-galloyl- $\beta$-d-glucopyranosyl)-3,5-dihydroxyacetophenone) (1): Brown amorphous powder; $[\alpha]_{\mathrm{D}}^{20}-13.1^{\circ}\left(C\right.$ 0.25, MeOH); UV $\lambda_{\max }(\mathrm{MeOH}): 220,278 \mathrm{~nm} ;{ }^{1} \mathrm{H}$ NMR (500 MHz, $\left.\mathrm{CH}_{3} \mathrm{OH}-d_{4}\right)$ and ${ }^{13} \mathrm{C}$ NMR (125 MHz, $\left.\mathrm{CH}_{3} \mathrm{OH}-d_{4}\right)$, see Table 2; (+)-HR-ESIMS m/z $505.0953[\mathrm{M}+\mathrm{Na}]^{+}$(calcd $\left.\mathrm{C}_{21} \mathrm{H}_{22} \mathrm{O}_{13} \mathrm{Na}, 505.0958\right)$. 
Gadipyrone (5-isopropyl-2-oxo-3,6-dihydropyran-4-carboxylic acid) (2): White crystal; UV $\lambda_{\max }(\mathrm{MeOH}): 220 \mathrm{~nm}$; IR v: 3451, 1752, 1690 and $1645 \mathrm{~cm}^{-1} ;{ }^{1} \mathrm{H}$ NMR $\left(500 \mathrm{MHz}, \mathrm{CH}_{3} \mathrm{OH}-d_{4}\right)$ and ${ }^{13} \mathrm{C}$ NMR $\left(125 \mathrm{MHz}, \mathrm{CH}_{3} \mathrm{OH}-d_{4}\right)$, see Table 2; (+)-HR-ESI-MS $\mathrm{m} / z 207.0628[\mathrm{M}+\mathrm{Na}]^{+}$ (calcd $\mathrm{C}_{9} \mathrm{H}_{12} \mathrm{O}_{4} \mathrm{Na}, 207.0633$ ).

\subsection{Chemical screening of plant extracts}

The total phenolic and flavonoid contents of $\mathrm{PE}, \mathrm{CHCl}_{3}, \mathrm{EtOAc}$ and $n$ - $\mathrm{BuOH}$ extracts were established using Folin-Ciocalteu and trichloroaluminum methods (See supplementary material).

\subsection{Antioxidant activity}

The antioxidant activity of the extracts, fractions and isolated compounds was evaluated by DPPH free radical scavenging and Cupric reducing antioxidant capacity (CUPRAC) assays (See supplementary material).

\subsection{Tyrosinase inhibitory activity}

The extracts, fractions and $\mathbf{1}$ and $\mathbf{2}$ were tested for their tyrosinase inhibitory activity (See supplementary material).

\section{Statistical analysis}

All data on bioassays were the average of triplicate analyses. The data were recorded as mean values \pm standard deviation. The $\mathrm{IC}_{50}$ and $\mathrm{A}_{0.5}$ values were calculated by linear regression analysis. 


\section{Supplementary material}

General methods, UV, IR, HR-ESI-MS, ${ }^{1} \mathrm{H}$ and ${ }^{13} \mathrm{C}$ NMR, COSY, HSQC, HMBC and NOESY spectra of the previously unreported compounds $\mathbf{1}$ and $\mathbf{2}$ are available online.

\section{Acknowledgements}

The authors are grateful to the DGRSDT of the Ministry of Higher Education and Scientific Research of Algeria for PRFU Project (B00L01UN050120180001), Biotechnology Research Centre (CRBt) (Constantine-Algeria), Conseil Regional Champagne-Ardenne, Conseil General de la Marne, Ministry of Higher Education and Research (MESR) France and EU-program FEDER to the PlAneT CPER project.

\section{Disclosure statement}

No potential conflict of interest was reported by the authors.

\section{References}

Aichour, S., Haba, H., Benkhaled, M., Harakat, D., Lavaud, C., 2014. Terpenoids and other constituents from Euphorbia bupleuroides. Phytochem. Lett. 10, 198-203.

Badaoui, M.I., Alabdul Magid, A., Benkhaled, M., Bensouici, C., Harakat, D., VoutquenneNazabadioko, L., Haba, H., 2019. Phytochemical study, antioxidant and anticholinesterase activities of Atractylis cancellata L. Nat. Prod. Res. 7, 1-7. doi.org/10.1080/14786419.2019.1682575. 
Benabdelaziz, I., Gomez-Ruiz, S., Benkhaled, M., Carralero, S., Schenker, P., Salm, A., Gertsch, J., Haba, H., 2018. New cycloartane-type ester triterpenes from Euphorbia pterococca and biological evaluation. Fitoterapia. 127, 271-278.

Benmerache, A., Alabdul Magid, A., Labed, A., Kabouche, A., Voutquenne-Nazabadioko, L., Hubert, J., Morjani, H., Kabouche, Z., 2017. Isolation and characterization of cytotoxic compounds from Euphorbia clementei Boiss. Nat. Prod. Res. 31, 2091-2098.

Budavari, S., O’Neil, M.J., Smith, A., Heckelman, P.E., 1989. The merck index. Merck \& CO., INC. $11^{\text {th }}$ edition, 699-700.

Chang, S.W., Kim, K.H., Lee, L.K., Choi, S.U., Ryu, S.Y., Lee, K.R., 2009. Phytochemical constituents of Bistorta manshuriensis. Nat. Prod. Sci. 15, 234-240.

Chen, H., Li, M., Zhang, C., Du, W., Shao, H., Feng, Y., Zhang, W., Yang, S., 2018. Isolation and identification of the anti-oxidant constituents from Loropetalum chinense (R. Brown) oliv. based on UHPLC-Q-TOF-MS/MS. Molecules. 23, 1720.

Cho, J.Y., Lee, K.D., Park, S.Y., Jeong, W.C., Moon, J.H., Ham, K.S., 2013. Isolation and identification of $\alpha$-glucosidase inhibitors from the stem bark of the nutgall tree (Rhus javanica L.). J. Korean. Soc. Appl. Biol. Chem. 56, 547-552.

Cui, L., Xing, M., Xu, L., Wang, J., Zhang, X., Ma, C., Kang, W., 2018. Antithrombotic components of Malus halliana Koehne flowers. Food Chem. Toxicol. 119, 326-333.

Davies-Coleman, M.T., Rivett, D.E.A., 1989. Stereochemical studies on boronolide, an $\alpha$-pyrone from Tetradenia barberae. Phytochemistry. 26 (11), 3047-3050. 
Dugé de Bernonville, T., Guyot, S., Paulin, J.P., Gaucher, M., Loufrani, L., Henrion, D., Derbré, S., Guilet, D., Richomme, P., Dat, J.F., Brisset, M.N., 2009. Dihydrochalcones: Implication in resistance to oxidative stress and bioactivities against advanced glycation end-products and vasoconstriction. Phytochemistry. 71, 443-452.

El-Toumy, S.A., Salib, J.Y., Mohamed, W.M., Morsy, F.A., 2010. Phytochemical and antimicrobial studies on Acacia saligna leaves. Egypt. J. Chem. 53, 705-717.

Flores-Giubi, M.E., Duran-Pena, M.J., Botubol-Ares, J.M., Escobar-Montaño, F., Zorrilla, D., Macías-Sanchez, A.J., Hernandez-Galań, R., 2017. Gaditanone, a diterpenoid based on an unprecedented carbon skeleton isolated from Euphorbia gaditana. J. Nat. Prod. 80, 21612165.

Fons, F., Rapior, S., Gueiffier, A., Roussel, J.L., Gargadennec, A., Andary, A., 1998. (E)-pcoumaroyl-1-O- $\beta$-D-glucopyranoside accumulation in roots of Plantago lanceolata cultures. Acta. Bot. Gallica. 14, 249-255.

Gomaa Darwish, A.G., Samy, M.N., Sugimoto, S., Otsuka, H., Abdel-Salam, H., Matsunami, K., 2016. Effects of hepatoprotective compounds from the leaves of Lumnitzera racemosa on acetaminophen-induced liver damage in vitro. Chem. Pharm. Bull. 64, 360-365.

Haba, H., Lavaud, C., Alabdul Magid, A., Benkhaled, M., 2009. Diterpenoids and triterpenoids from Euphorbia retusa. J. Nat. Prod. 72 (7), 1258-1264.

Haba, H., Marcourt, L., Benkhaled, M., Long, C., 2013. Minor ent-abietane diterpenoids from Euphorbia guyoniana. Nat. Prod. Commun. 8 (11), 1519-1522. 
Hilbert, G., Temsamani, H., Bordenave, L., Pedrot, E., Chaher, N., Cluzet, S., Delaunay, J.C., Ollat, N., Delrot, S., Mérillon, J.M., Gomès, E., Richard, T., 2014. Flavonol profiles in berries of wild Vitis accessions using liquid chromatography coupled to mass spectrometry and nuclear magnetic resonance spectrometry. Food Chem. 169, 49-58.

Huang, S.S., Li, P., Zhang, B.J., Deng, S., Zhang, H.L., Sun, C.P., Huo, X.K., Tian, X.G., Ma, X.C., Wang, C., 2017. Acetophenone glycosides from the roots of Euphorbia fischeriana and their inhibitory effects against Mycobacterium smegmatis. Phytochem. Lett. 19, 151155.

Isobe, T., Kanazawa, K., Fujimura, M., Noda, Y., 1981. Flavonoides of Polygonum seiboldi and P. filiforme. B. Chem. Soc. Jpn. 54, 3239.

Jancovicova, V., Ceppan, M., Havlinova, B., Rehacova, M., Jakubikova, Z., 2007. Interaction in iron gall inks. Chem. Pap. 61 (5), 391-397.

Lee, I.S., Jung, S.H., Kim, C.S., Kim, J.S., 2017. Phenolic compounds from the leaves of Homonoia riparia and their inhibitory effects on advanced glycation end product formation. Nat. Prod. Sci. 23, 274-280.

Li, H., Miyahara, T., Tezuka, Y., Namba, T., Nemoto, N., Tonami, S., Seto, H., Tada, T., Kadota, S., 1998. The effect of kampo formulae on bone resorption in vitro and in vivo. Biol. Pharm. Bull. 21, 1322-1326.

Li, L., Seeram, N.P., 2011. Further investigation into maple syrup yields three new lignans, a new phenylpropanoid, and twenty-six other phytochemicals. J. Agric. Food Chem. 59, 7708-7716. 
Lin, W.H., Deng, Z.W., Lei, H.M., Fu, H.Z., Li, J., 2002. Polyphenolic compounds from the leaves of Koelreuteria paniculata Laxm. J. Asian Nat. Prod. Res. 4, 287-295.

Liu, R., Quighua, S., Ailing, S., Jichun, C., 2005. Isolation and purification of coumarin compounds from Cortex fraxinus by high-speed counter-current chromatography. Journal of Chromatography A. 1072, 195-199.

Liu, T., Liang, Q., Zhang, X.M., Su, X.M., Qin, J.C., Li, G.Q., Xu, W.H., 2019. Chemical constituents from Euphorbia stracheyi Boiss. Biochem. Syst. Ecol. 84, 52-54.

Liu, Y., Rakotondraibe, L.H., Brodie, J.P., Wiley, D.J., Cassera, B.M., Miller, S.J., Ratovoson, F., Rakotobe, E., Rasamison, E.V., Kingston, G.I.D., 2015. Antimalarial 5,6-dihydro- $\alpha$ pyrones from Cryptocarya rigidifolia: related bicyclic tetrahydro- $\alpha$-pyrones are artifacts. J. Nat. Prod. 78, 1330-1338.

Mao, Z., Sun. W., Fu, L., Luo, H., Lai, D., Zhou, L., 2014. Natural dibenzo- $\alpha$-pyrones and their bioactives. Molecules. 19, 5088-5108.

Matsubara, Y., Yusa, T., Sawabe, A., Iizuka, Y., Okamoto, K., 1991. Structure and physiological activity of phenyl propanoid glycosides in lemon (Citrus limon Burm. f.) peel. Agric. Biol. Chem. 55, 647-650.

Menozzi Smarrito, C., Munari, C., Robert, F., Barron, D., 2008. A novel efficient and versatile route to the synthesis of 5-O-feruloylquinic acids. Org. Biomol. Chem. 6, 986-987.

Mouffouk, S., Gomez-Ruiz, S., Benkhaled, M., Carralero, S., Haba, H., 2019. Phytochemical composition, antioxidant and antibacterial activities of crude extracts from the speciesEuphorbia atlantica Coss. Pharm. Chem. J. 53 (9), 831-837. 
Onocha, P.A., Okorie, D.A., Connolly, J.D., Roycroft, D.S., 1995. Monotérpene diol, iridoid glucoside and dibenzo- $\alpha$-pyrane from Anthocleista djalonensis. Phytochemistry. 40, 11831189.

Özbilgin, S., Citoğlu, G.S., 2012. Uses of some Euphorbia species in traditional medicine in turkey and their biological activities. Turk. J. Pharma. Sci. 9, 241-256.

Rice-Evans, C.A., Miller, N.J., Paganga, G., 1996. Structure-antioxidant activity relationships of flavonoids and phenolic acids. Free Radic. Biol. Med. 20, 933-956.

Sakushima, A., Coskun, M., Hisada, S., Nishibe, S., 1983. Flavonoids from Rhamnus pallash. Phytochemistry. 22, 1677-167.

Satake, T., Kamiya, K., An, Y., Oishi, T. (Taka, N.,), Yamamoto, J., 2007. The anti-thrombotic active constituents from Centella asiatica. Biol Pharm Bull. 30, 935-940.

Schäberle, T.F., 2016. Biosynthesis of $\alpha$-pyrone. Beilstein J. Org. Chem. 12, 571-588.

Shi, Q.W., Su, X.H., Kiyota, H., 2008. Chemical and pharmacological research of the plants in genus Euphorbia. Chem. Rev. 108, 4295-4327.

Singla, A.K., Pathak, K., 1990. Phytoconstituents of Euphorbia species. Fitoterapia. 41, 483-516.

Son, B.W., Park, J.H., Zee, O.P., 1989. Catechin glycoside from Ulmus davidiana. Arch. Pharm. $12,219-222$.

Sun, D., Zhao, Z., Lai, Y.F., Herbert, W., 1991. Flavonoids from Myrica esculenta bark. Chemistry and Industry of Forest Products. 11, 251-255. 
Swisłocka, R., Kowczyk-Sadowy, M., Kalinowska, M., Lewandowski, W., 2012. Spectroscopic (FT-IR, FT-Raman, ${ }^{1} \mathrm{H}$ and ${ }^{13} \mathrm{C}$ NMR) and theoretical studies of $p$-coumaric acid and alkalimetal p-coumarates. Spectroscopy. 27, 35-48.

Zaghloul, AM., 1993. New flavonoid glycosides from Euphorbia dracunculoides. Man. J. Pharm. Sci. 9, 204-212.

Zhu, X., Dong, X., Wang, Y., Ju, P., Luo, S., 2005. Phenolic compounds from Viburnum cylindricum. Helv. Chim. Acta. 88, 339-342. 

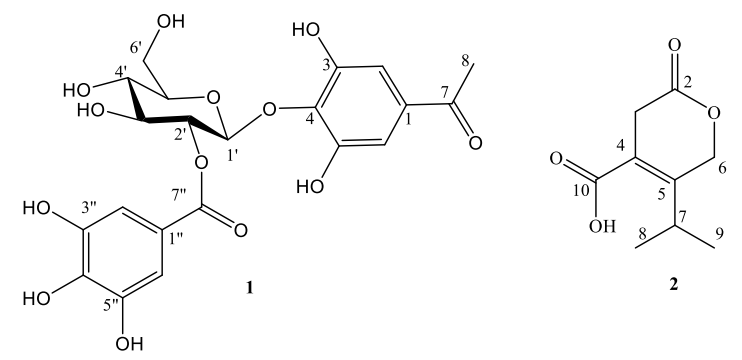

Fig. 1. Chemical structures of the two previously unreported compounds $\mathbf{1}$ and $\mathbf{2}$ isolated from E. gaditana.

Table 1. Phenolic and flavonoid contents in E. gaditana extracts

\begin{tabular}{lll}
\hline Extracts & TPC $(\mathbf{m g ~ G A E} / \mathbf{g})$ & TFC $\left(\mathbf{m g ~ Q E}^{\mathrm{y} / \mathrm{g}}\right)$ \\
\hline $\mathbf{P E}$ & $6.32 \pm 1.43$ & $1.17 \pm 0.25$ \\
$\mathbf{C H C l}_{3}$ & $29.39 \pm 1.98$ & $11.70 \pm 1.51$ \\
$\mathbf{E t O A c}$ & $189.87 \pm 1.32$ & $91.31 \pm 1.35$ \\
$\boldsymbol{n}$-BuOH & $109.26 \pm 1.43$ & $37.16 \pm 2.40$ \\
\hline${ }^{\mathrm{x}}$ Gallic acid equivalent, ${ }^{\mathrm{y}}$ quercetin equivalent
\end{tabular}


Table 2. ${ }^{1} \mathrm{H}$ and ${ }^{13} \mathrm{C}$ NMR data of compounds $\mathbf{1}$ and $2\left(500\right.$ and $\left.125 \mathrm{MHz}, \mathrm{CH}_{3} \mathrm{OH}-d_{4}\right)$

\begin{tabular}{|c|c|c|c|c|c|}
\hline \multirow{2}{*}{ Position } & \multicolumn{2}{|c|}{1} & \multirow{2}{*}{ Position } & \multicolumn{2}{|c|}{2} \\
\hline & $\delta_{\mathrm{H}}, \mathrm{m}(J$ in $\mathrm{Hz})$ & $\delta_{\mathrm{C}}$, type & & $\delta_{\mathrm{H}}, \mathrm{m}(J$ in $\mathrm{Hz})$ & $\delta_{\mathrm{C}}$, type \\
\hline 1 & - & $107.3(\mathrm{C})$ & 2 & - & $173.3(\mathrm{CO})$ \\
\hline 2 & $5.98, \mathrm{~s}$ & $96.3(\mathrm{CH})$ & 3 & $3.33, \mathrm{t}(1.8)$ & $32.8 \quad\left(\mathrm{CH}_{2}\right)$ \\
\hline 3 & - & $165.5(\mathrm{C})$ & 4 & - & $121.0(\mathrm{C})$ \\
\hline 4 & - & $164.9(\mathrm{C})$ & 5 & - & $152.8(\mathrm{C})$ \\
\hline 5 & - & $165.5(\mathrm{C})$ & 6 & $4.95, \mathrm{t}(1.8)$ & $68.2\left(\mathrm{CH}_{2}\right)$ \\
\hline 6 & $5.98, \mathrm{~s}$ & $96.3(\mathrm{CH})$ & 7 & $3.87, \mathrm{~m}$ & $29.8 \quad(\mathrm{CH})$ \\
\hline 7 & - & $205.3(\mathrm{CO})$ & 8 & $1.09, \mathrm{~d}(7.0)$ & $20.1 \quad\left(\mathrm{CH}_{3}\right)$ \\
\hline 8 & $2.60, \mathrm{~s}$ & $33.0\left(\mathrm{CH}_{3}\right)$ & 9 & $1.09, \mathrm{~d}(7.0)$ & $20.1 \quad\left(\mathrm{CH}_{3}\right)$ \\
\hline $1^{\prime}$ & $5.21, \mathrm{~d}(8.1)$ & $99.7(\mathrm{CH})$ & 10 & - & $168.1(\mathrm{CO})$ \\
\hline $2^{\prime}$ & $5.12, \mathrm{dd}(9.5,8.1)$ & $74.9(\mathrm{CH})$ & & & \\
\hline $3^{\prime}$ & $3.74, \mathrm{t}(9.1)$ & $76.1(\mathrm{CH})$ & & & \\
\hline $4^{\prime}$ & $3.53, \mathrm{t}(9.0)$ & $71.6(\mathrm{CH})$ & & & \\
\hline $5^{\prime}$ & $3.57, \mathrm{~m}$ & $78.5(\mathrm{CH})$ & & & \\
\hline 6'a & $3.77, \mathrm{dd}(12.1,5.1)$ & $62.3\left(\mathrm{CH}_{2}\right)$ & & & \\
\hline $6 ' b$ & $3.96, \mathrm{dd}(12.1,1.9)$ & & & & \\
\hline $1 "$ & - & $121.3(\mathrm{C})$ & & & \\
\hline $2^{\prime \prime}$ & $7.07, \mathrm{~s}$ & $110.3(\mathrm{CH})$ & & & \\
\hline $3 "$ & - & $146.5(\mathrm{C})$ & & & \\
\hline $4 "$ & - & $140.0(\mathrm{C})$ & & & \\
\hline $5 "$ & - & $146.5(\mathrm{C})$ & & & \\
\hline 6" & $7.07, \mathrm{~s}$ & $110.3(\mathrm{CH})$ & & & \\
\hline $7 "$ & - & $167.6(\mathrm{CO})$ & & & \\
\hline
\end{tabular}


Table 3. Antioxidant (DPPH and CUPRAC assays) and tyrosinase inhibitory activity of $E$. gaditana extracts, fractions, and compounds (1-31)

\begin{tabular}{|c|c|c|c|}
\hline \multirow{3}{*}{$\begin{array}{l}\text { Extracts/ Fractions/ } \\
\text { Compounds }\end{array}$} & \multicolumn{2}{|c|}{ Antioxidant activities } & \multirow[t]{2}{*}{ Tyrosinase activity } \\
\hline & DPPH assay & CUPRAC assay & \\
\hline & $\mathrm{IC}_{50}(\mu \mathrm{g} / \mathrm{mL})$ & $\mathrm{A}_{0.5}(\mu \mathrm{g} / \mathrm{mL})$ & $\mathrm{IC}_{50}(\mu \mathrm{g} / \mathrm{mL})$ \\
\hline PE extract & $>200$ & $>200$ & $>200$ \\
\hline $\mathrm{CHCl}_{3}$ extract & $>200$ & $61.2 \pm 0.35$ & $>200$ \\
\hline EtOAc extract & $8.28 \pm 0.88$ & $6.44 \pm 1.09$ & $>200$ \\
\hline$n$-BuOH extract & $11.23 \pm 0.66$ & $15.94 \pm 1.07$ & $>200$ \\
\hline Ac1 & $3.98 \pm 0.43$ & $13.38 \pm 0.78$ & $>200$ \\
\hline Ac2 & $2.86 \pm 0.29$ & $8.72 \pm 0.26$ & $35.39 \pm 2.92$ \\
\hline Ac3 & $4.78 \pm 0.44$ & $11.68 \pm 0.09$ & $>200$ \\
\hline Ac4 & $30.82 \pm 2.57$ & $59.41 \pm 1.37$ & $>200$ \\
\hline Bu0 & $56.27 \pm 1.13$ & $107.89 \pm 1.45$ & $>200$ \\
\hline Bu1 & $5.27 \pm 0.73$ & $12.68 \pm 0.44$ & $>200$ \\
\hline Bu2 & $3.59 \pm 0.13$ & $10.85 \pm 0.29$ & $32.16 \pm 2.18$ \\
\hline Bu3 & $6.15 \pm 0.1$ & $22.11 \pm 0.24$ & $15.23 \pm 0.87$ \\
\hline Bu4 & $4.09 \pm 0.2$ & $21.40 \pm 0.12$ & $88.25 \pm 1.16$ \\
\hline 1 & $3.25 \pm 0.09$ & $7.09 \pm 0.1$ & $89.78 \pm 0.93$ \\
\hline 2 & NA & NA & $52.39 \pm 0.69$ \\
\hline 3 & $3.40 \pm 0.06$ & $4.20 \pm 0.42$ & - \\
\hline 4 & $0.89 \pm 0.13$ & $2.20 \pm 0.26$ & - \\
\hline 5 & $3.0 \pm 0.14$ & $6.32 \pm 0.07$ & - \\
\hline 6 & $3.32 \pm 0.34$ & $9.79 \pm 1.15$ & - \\
\hline 7 & $31.34 \pm 1.11$ & $72.98 \pm 1.29$ & - \\
\hline 8 & $1.12 \pm 0.19$ & $8.13 \pm 0.34$ & - \\
\hline 9 & $2.61 \pm 0.11$ & $10.37 \pm 0.09$ & - \\
\hline 10 & $3.52 \pm 1.20$ & $11.59 \pm 0.45$ & - \\
\hline 11 & $2.87 \pm 0.21$ & $11.01 \pm 0.11$ & - \\
\hline 12 & $9.94 \pm 0.86$ & $18.02 \pm 0.71$ & - \\
\hline 13 & $18.36 \pm 0.76$ & $21.38 \pm 0.72$ & - \\
\hline 14 & $5.59 \pm 0.39$ & $11.19 \pm 0.24$ & - \\
\hline 15 & $8.12 \pm 0.12$ & $11.88 \pm 0.39$ & - \\
\hline 16 & $8.6 \pm 0.38$ & $12.77 \pm 0.35$ & - \\
\hline 17 & $3.34 \pm 0.27$ & $10.52 \pm 0.75$ & - \\
\hline 18 & $3.18 \pm 0.33$ & $10.13 \pm 0.89$ & - \\
\hline 19 & $2.8 \pm 0.58$ & $10.64 \pm 0.36$ & - \\
\hline 20 & $2.51 \pm 0.23$ & $10.30 \pm 0.78$ & - \\
\hline 21 & $19.49 \pm 0.77$ & $19.44 \pm 1.19$ & - \\
\hline 22 & $>200$ & $\begin{array}{l}83.84 \pm 1.54 \\
27\end{array}$ & - \\
\hline
\end{tabular}




$\begin{array}{llll}\mathbf{2 3} & 153.7 \pm 0.8 & 75.43 \pm 0.38 & - \\ \mathbf{2 4} & 98.7 \pm 2.6 & 11.64 \pm 0.55 & - \\ \mathbf{2 5} & 5.78 \pm 0.09 & 8.10 \pm 0.67 & - \\ \mathbf{2 6} & 30.84 \pm 1.23 & 40.32 \pm 1.33 & - \\ \mathbf{2 7} & 8.23 \pm 0.2 & 10.43 \pm 0.68 & - \\ \mathbf{2 8} & 17.99 \pm 1.11 & 13.04 \pm 0.28 & - \\ \mathbf{2 9} & 39.3 \pm 1.94 & 5.83 \pm 0.5 & - \\ \mathbf{3 0} & 1.01 \pm 0.07 & 2.25 \pm 0.15 & - \\ \mathbf{3 1} & >200 & 16.0 \pm 0.84 & - \\ \text { BHT } & 12.99 \pm 0.41 & 8.97 \pm 3.94 & - \\ \text { Ascorbic acid } & 13.94 \pm 2.81 & 52.59 \pm 1.98 & - \\ \text { Kojic acid } & - & - & 25.23 \pm 0.78\end{array}$

$\mathrm{IC}_{50}$ values are defined as the concentration of $50 \%$ inhibition percentages, $\mathrm{A}_{0.5}$ values are defined as the concentration at absorbance $\mathrm{A}=0.5$ and calculated by linear regression analysis and expressed as Mean \pm SD $(n=3)$. NA: not absorbed. 